術期口腔管理による術後肺炎予防. 口㬶感染症誌. 2006; $13: 25-8$

受付日 2006 年 9 月 29 日 採択日 2008 年 1 月 4 日

\section{intensive care unit stay}

To the Editor: Hiromitsu Kishimoto*1, Ryu Okutani*2

${ }^{* 1}$ Department of Oral and Maxillofacial Surgery, ${ }^{* 2}$ Intensive Care Unit, Hyogo College of Medicine Hospital

(1-1 Mukogawa-cho, Nishinomiya, Hyogo 663-8501, Japan)

J Jpn Soc Intensive Care Med. 2008;15:347 348.

\title{
セプシスに対する免疫グロブリン使用の是非
}

\section{編集委員長殿}

ご存知の方も多いと思うが, 雑誌「Critical Care Medicine (CCM)」の 2007年 12 月号に, セプシスに対 する静注用免疫グロブリン (intravenous immunoglobulin, IVIg)の効果に関する2つのメタアナリシス, 1つの無作為比較試験 (randomized controlled trial, $\mathrm{RCT})$ ，および2つの論説が掲載された1) 5)。同じ話 題でこれだけ多くの文献が同時に掲載されるというの は異例のことであり, IVIgに対する国際的な関心の高 さを示しているものと思われる。本邦においても IVIgは重症感染症の治療薬として広く使用されてい るが, その根拠はそしいものと言わざるを得ない6)。

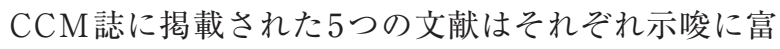
むものであり, 改めて本邦におけるIVIg使用の是非に ついて考えてみたい。

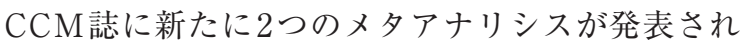
たことにより, IVIgに関するメタアナリシスは著者の

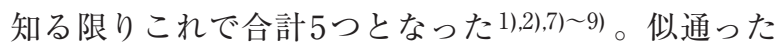
研究を解析し, 似通った結果を出し(すべての研究に おいて IVIgの relative risk は1未満)，異なった結論を 出している(“有効である”から“使用すべきでない”ま で）。この点に関しては論説に詳しく記載があるため, ここでは割愛するが, funnel plotで明らかなpublication biasが示されていること, $1 \mathrm{~g} \cdot \mathrm{kg}^{-1}$ 以下 (つま り体重 $60 \mathrm{~kg}$ で60 g) は低用量（！）として扱われてい ることはここに記載しておきたい。
The Score-Based Immunoglobulin Therapy of Sepsis (SBITS) studyは, IVIgに関する研究のうち, primary outcomeを死亡率とした RCTとしては最大 のものである3)。653例に対してIVIg $0.9 \mathrm{~g} \cdot \mathrm{kg}^{-1}$ 投 与群とプラセボ投与群を比較し, 28 日死亡率はIVIg 群が $39.3 \%$, プラセボ群が $37.3 \%$ でった。研究が終 了してから発表されるまで 10 年以上が経過しており， 発表が待たれていた文献である。この研究が文献とし て発表されたことにより, IVIgの効果に関するエビデ ンスのレベルは大きく向上したと思われる。

論説 2 編は共にIVIgの有効性の低さについて, およ びIgMやIgA を配合した製剤 (IVIgGMA) の有効性に ついて論じている4),5)。しかし, IVIgGMA使用に関す る根拠も決して高いものではなく, 一番大きな RCT で200例程度を対象としており, かつ, その研究は否 定的な結果となっている10)。どちらにしろ,このよう な製剤は本邦では発売されていない。

本邦でのIVIg 使用の根拠となっている研究は, 主に 血液疾患に対する抗癌薬治療中に起こった発熱に対し て検討され, 非盲検的に行われた（対象症例682例中, 死亡例は 18 例 $)^{6)}$ 。投与後7日目までの解熱率はIVIg 群 $54.8 \%$, 対照群 $37.2 \%$ であった。つまり平たく言え ば, IVIgを死亡率の高くない疾患群に投与すると熱が 下がる確率が高くなることを示した研究である。体温 はあくまで重症感染症に対する治療効果を判定する上 
ではsurrogate markerであり（解熱が感染の改善によ るものであるとするのはあくまで仮定もしくは期待に 過ぎない), この結果がそのままIVIgの有効性を示す ことにはつながらない。また, 死亡率が $3 \%$ 未満と低 く, ICUにおける重症感染症とは疾患群が非常に異な る。ちなみに, IVIgの感染症に対する効果を検証した 研究では世界最大級であるにもかかわらず, 日本語で 発表されていること, 死亡率を outcomeとしていない こと等の理由により, ほとんどのメタアナリシスには 含まれていない9)。

以上をまとめると, 本邦では, 有効性がそしいと考 えられるIVIgを, 熱が下がる例が増えるからという根 拠で, 国際標準の四分の一程度の量で使用している, ということになる。医療費削減の問題が叫ばれる中, 根拠と有効性と価格が釣り合わない治療に対して, 我々はもっと撖密であるべきではないだろうか。

\section{内野 滋彦}

\section{東京慈恵会医科大学麻酔科集中治療部}

（１05-8471＼cjkstart東京都港区西新橋3-19-18）

\section{文 献}

1) Kreymann KG, de Heer G, Nierhaus A, et al. Use of polyclonal immunoglobulins as adjunctive therapy for sepsis or septic shock. Crit Care Med. 2007;35:2677-85.

2) Laupland KB, Kirkpatrick AW, Delaney A. Polyclonal intravenous immunoglobulin for the treatment of severe sepsis and septic shock in critically ill adults: a systematic review and meta-analysis. Crit Care Med. 2007;35:2686-92.

3) Werdan K, Pilz G, Bujdoso O, et al. Score-based immuno- globulin G therapy of patients with sepsis: The SBITS study. Crit Care Med. 2007;35:2693-701.

4) Werdan K. Mirror, mirror on the wall, which is the fairest meta-analysis of all? Crit Care Med. 2007;35:2852-4.

5) Neugebauer EA. To use or not to use? Polyclonal intravenous immunoglobulins for the treatment of sepsis and septic shock. Crit Care Med. 2007;35:2855-6.

6) 正岡 徹, 長谷川廣文, 高久史麿, 他. 重症感染症に対す る抗菌薬との併用療法における静注用ヒト免疫グロブリン の効果. 日化療会誌. 2000;48:199-217.

7) Alejandria MM, Lansang MA, Dans LF, et al. Intravenous immunoglobulin for treating sepsis and septic shock. Cochrane Database Syst Rev. 2002;1:CD001090.

8) Pildal J, Gotzsche PC. Polyclonal immunoglobulin for treatment of bacterial sepsis: a systematic review. Clin Infect Dis. 2004;39:38-46.

9) Turgeon AF, Hutton B, Fergusson DA, et al. Meta-analysis: intravenous immunoglobulin in critically ill adult patients with sepsis. Ann Intern Med. 2007;146:193-203.

10) Hentrich M, Fehnle K, Ostermann H, et al. IgMAenriched immunoglobulin in neutropenic patients with sepsis syndrome and septic shock: a randomized, controlled, multiple-center trial. Crit Care Med. 2006;34: 1319-25.

受付日 2007 年 12 月 19 日 採択日 2008 年 1 月 15 日

\section{Intravenous immunoglobulin for sepsis: to use or not to use?}

\section{To the Editor: Shigehiko Uchino}

Intensive Care Unit, Department of Anesthesiology, Jikei University of Medicine

(3-19-18 Nishishinbashi, Minato-ku, Tokyo 105-8471, Japan)

J Jpn Soc Intensive Care Med. 2008;15:348 349. 